\title{
Analyzing the heritage potential of a temple town using GIS - A Case study of Kumbakonam
}

\author{
G.Yogapriya \\ Research Scholar, Department of Architecture \\ Periyar Maniammai University, Thanjavur, Tamilnadu, India \\ Dr.S.Senthamil Kumar \\ Periyar Maniammai University, Thanjavur, Tamilnadu, India
}

\begin{abstract}
Recent years, the role of GIS as a tool in decision making in macro level planning, tourism and sustainable development is active. As it works in layers with a stored database using cartographic points, it figures out the issues of a complex problem. Kumbakonam, known for its Mahamaham festival conducted once in 12 years is taken for analysis. The heritage potential of the town is examined through the data's collected from site visits, case study and book reviews. Heritage town potentials can be classified as tangible and intangible characters. After identifying, the tangible aspects are marked in GIS as a point and polygon. The land use map is also generated using digitization method. The result shows the varied heritage potential in closer proximity and storing the same for analyzing will help in developing a sustainable strategy for the temple town.
\end{abstract}

Keywords - GIS, Spatial Data, Digitization, Heritage, Temple Town

\section{INTRODUCTION}

UNESCO has acknowledged heritage as the one which could be inherited from the past and passed to future generation. The experience of the travelers on visiting destinations possessing a special cultural, historical or natural value, may be a group of people sometimes, refers to heritage tourism. One of the ways of passing and protecting the heritage for future generation can be through the means of sustainability, which protects the environment, promotes economical growth with social equity. Unless and until the data's are documented and analyzed it is tough for the future generation to know about the authenticity of any location. In that case, the spatial data is integrated, manipulated, visualized and analyzed in a GIS by exploring the conflicts. GIS is used as an information system for different types of operation like survey, data collection, storage, analysis and to derive at a solution for decision making. (Kim, 2002).Facts that can be used in a database management are known as database. (Clarke 2001).Database manager is a computer program where the facts can be structured, organized, recorded and maintained. This helps to sort, reorganize, search the data's and also generate reports and graphs. (Olukole, 2008).GIS is proven to be one of the most important technical advancement in planning and decision making in touristic information. Than other information systems, GIS is used to encode, store, manage, analyze and visualize the spatial and non spatial data. (Dye and Show, 2007).

\section{STUDY AREA}




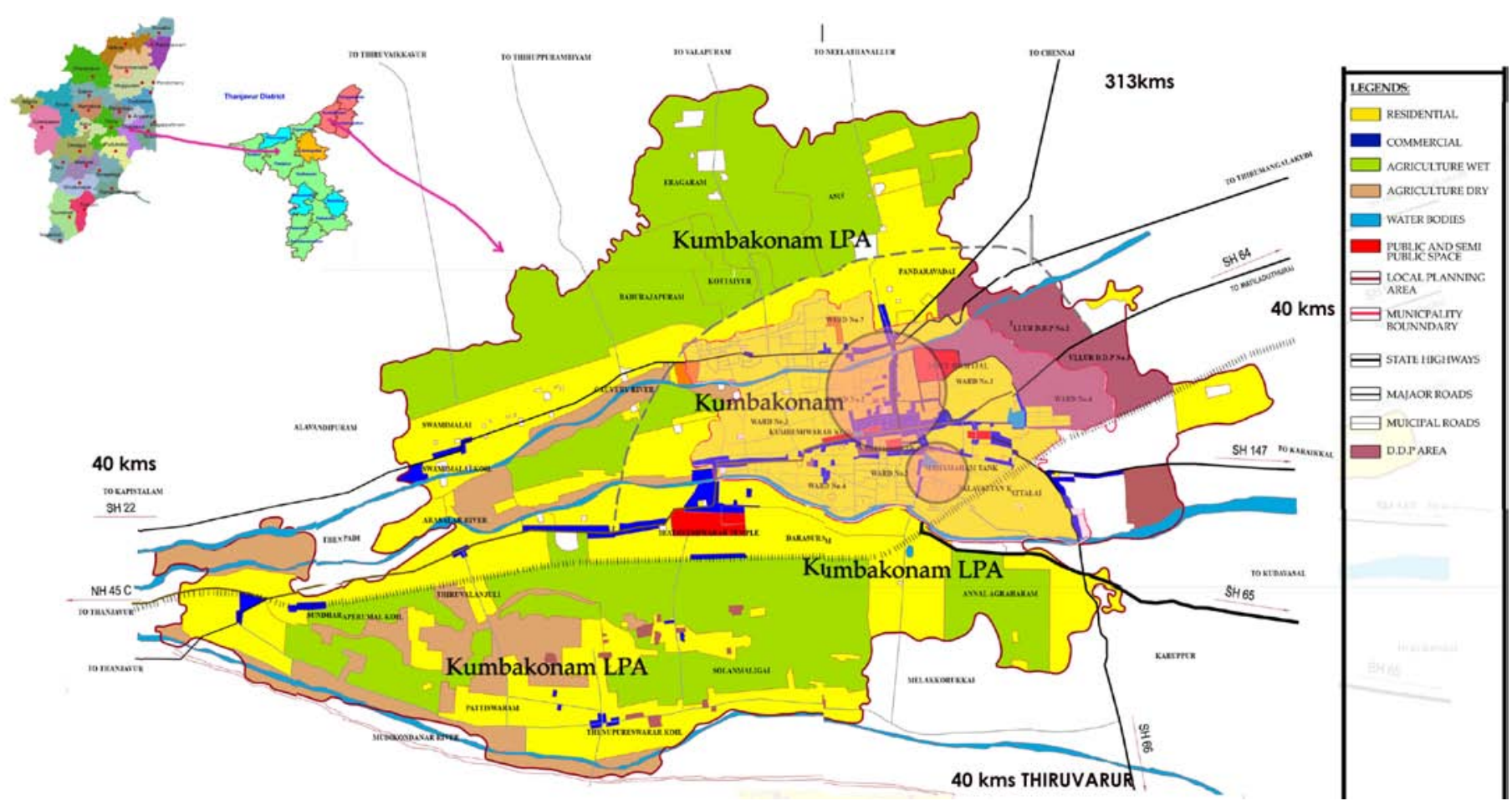

\section{A.KUMBAKONAM}

Kumbakonam - a place of rich cultural heritage and strong architectural character. It spreads over an area of 12.58 sq.km and according to census the population for the year 2016 is 170444 approx. This was one of the political capitals of the Chola dynasty. Since time unknown its stand as a symbol of our cultural heritage against all invasions. It is also one of the old Indian cities that still struggle to retain the rich cultural heritage. Like any other temple town which is single centered, Kumbakonam is a multicentered temple town with 180 temples in and around. Kumbakonam is one such city in Tamilnadu, along the Cauvery River; located in the delta between the Cauvery \& its tributary Arasalar. Fig 1 shows the historical importance of Kumbakonam and various periods of rules from different dynasty. Most of the Shiva temples were constructed during the Chola period. Vaishanavite Temple was built during Vijayanagar and Nayak period.

\section{B. CHRONOLOGY AND THE HERITAGE CHARACTERS}

The heritage potential of the town can be divided into tangible, intangible and material cultural heritage. Predominantly the Shiva temples constructed during Chola period stands from the year of 1200 A.D and Vaishnavite Temple from 1800 A.D. The Mahamagam Tank associated with the famous festival conducted once in 12 years and last time it was conducted in 2016. More than 10 lakh people took the holy dip in that day of festival. Masimagam is another predominant festival of the town conducted every year of Feb-Mar month. The temple structure which stands from earlier age is associated with the fairs and festivals conducted throughout the year. Thus the tangible heritage character like temples and tanks has been associated with the festivals with the intangible heritage characters. Other than this, intangible heritage characters comes from textiles, statues, bronze casting, and brassware have been prominent since the $9^{\text {th }}$ century AD. Unlike Arasalaru, in Cauvery rituals pertaining to river is enacted from earlier period. 


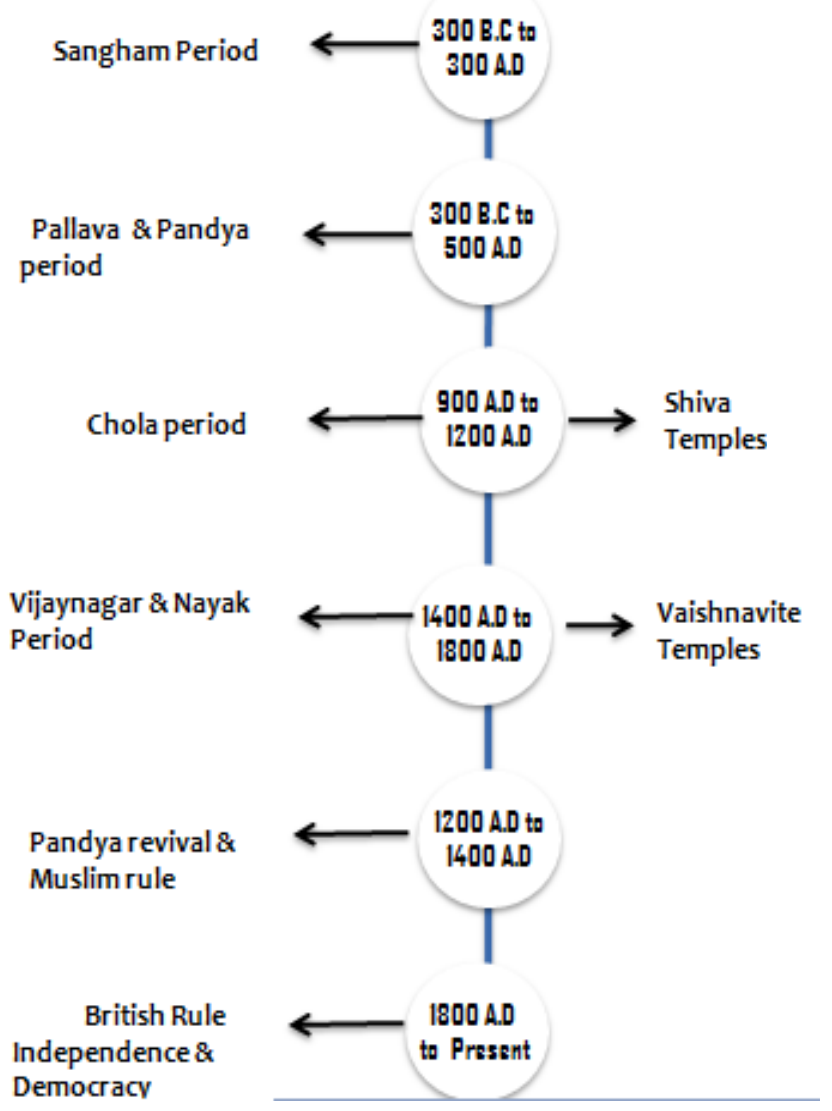

Fig 1

\section{GIS AND ITS APPLICATIONS}

All types of geographical data are acquired, operated, investigated and presented in GIS to merge the cartographical and statistical analysis for a database. As it works with the spatial areas, the system works in application way.GIS is used in various fields like tourism, urban planning, construction, solid waste management, mining, forestry, agriculture, transport, population control etc. In most of the cases it acts as a decision support system.

Georeferencing, attributes, spatial datas, non spatial datas, and analysis are common terminology used in GIS. The geographical region has cartographic points which have limits and boundaries. The source used in GIS are georefrenced according to the co ordinates and the details added to define it is spatial characters are known as spatial data's and other as non spatial data's. Arc catalog is the one which has shape files created with georeferenced cartographic points and used while digitizing. Maps are digitized from toposheets or from aerial photography to get the exact situation of an existing site.

\section{METHODS}

1. A toposheet of $58 \mathrm{~N} / 5$ is georeferenced in ArcGIS 9.3 version. The top sheet layer is kept in the GCS_WGS_1984 coordinate system. As the co ordinates in all the four corners have been already given in the toposheet, it is very useful to Georeference. Dell Laptop Inspiron 153000 series is used for digitization.

2. As the heritage character is present between the two main rivers, the study part is taken between the rivers of around 8 sq.km. A different type of shapes files is created in Arccatalog and it is added to the toposheet layer with the same co ordinate system.

3. The toposheet is mapped in the year 1970, there are open spaces seen in the map. The idea of the study is to identify the heritage potentials and the utilization of this map is suitable. 
4. After completing the digitization, tangible heritage characters are located in the map using the co ordinates as points, paths as line and temple precinct as polygon.

5. The heritage characters are collected by direct visit and interviews from the Kumbakonam Town area.

\section{ANALYSIS}
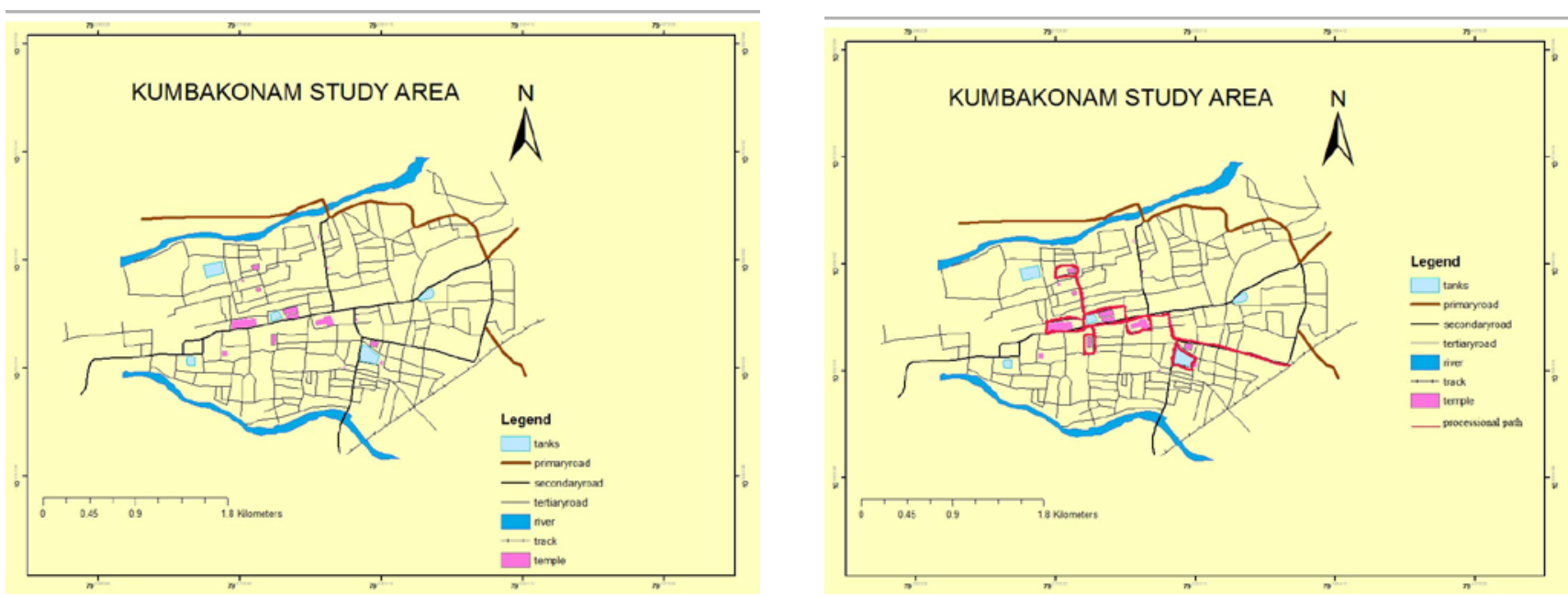

- After digitization, the temple area, commercial area and residential area were deeply analyzed. It shows that the town has more number of temple structures which have been placed all over the town area between the two rivers Arasalaru and Cauvery.

- There are few tanks which are placed in the temple precinct used for religious purpose, near the temple for the purpose of festivals and few tanks used for ablution purpose.

- The fairs and festivals are conducted in the temple region with the combination of tanks which adds to intangible cultural heritage of the town.

- Map showing the various processional paths is marked to understand how tangible and intangible characters play a vivid role in a heritage town.

- The whole town is seems to be covered with the residential area. There are also few slum area in the core of the town and nearer to the banks of the two river.

- The pavilions, ghats and secondary shrines are situated near the Cauvery River than Arasalaru.

- Table 1 shows the different temple and tanks in the selected study area and its shows its varied potential.

- These tables are added to attribute table of the GIS to get the clear picture of existing site and its cultural, heritage characters. 


\begin{tabular}{c|l|l|c|c|r|}
\hline S.NO & Tangible heritagee structures & Shape & Latitude & Longitude & Area \\
\hline 1 & Kumbeswara Temple & polygon & 10.958353 & 79.370221 & $4,601.18$ \\
\hline 2 & Nageswara Temple & polygon & 10.958743 & 79.378979 & $7,879.34$ \\
\hline 3 & Someswara Temple & polygon & 10.959078 & 79.37475 & $2,377.44$ \\
\hline 4 & Kalika Parameswari Temple & polygon & 10.96381 & 79.376092 & 755.69 \\
\hline 5 & Gauthameswarar Temple & polygon & 10.954854 & 79.379797 & 123.24 \\
\hline 6 & Banapuriswarar Temple & polygon & 10.964432 & 79.382288 & 225.04 \\
\hline 7 & Abimukeswarar Temple & polygon & 10.955086 & 79.382925 & $1,601.11$ \\
\hline 8 & Kambatta Viswanathar Temple & polygon & 10.956218 & 79.366846 & $1,242.95$ \\
\hline 9 & Ekambeswarar Temple & polygon & 10.958453 & 79.380847 & 298.33 \\
\hline 10 & Sarangapani Temple & polygon & 10.959557 & 79.375684 & $10,280.93$ \\
\hline 11 & Ramaswamy Temple & polygon & 10.957401 & 79.373667 & $5,700.07$ \\
\hline 12 & Varahaperumal Temple & polygon & 10.962136 & 79.370545 & 809.22 \\
\hline 13 & Adhikumbeshwar Temple & polygon & 10.958456 & 79.370646 & $17,368.97$ \\
\hline 14 & Brahma Temple & polygon & 10.954109 & 79.375757 & 520.83 \\
\hline 15 & chakrapani temple & polygon & 10.963315 & 79.372037 & $3,738.95$ \\
\hline 16 & Mahamaham Tank & polygon & 10.955662 & 79.382105 & $24,005.20$ \\
\hline 17 & Potramarai Tank & polygon & 10.959056 & 79.374021 & $6,956.07$ \\
\hline 18 & Reddy Roa Tank & polygon & 10.963287 & 79.368306 & $25,747.54$ \\
\hline 19 & Pidari Tank & polygon & 10.960913 & 79.386942 & $9,448.81$ \\
\hline 20 & Saraya Pond & polygon & 10.955323 & 79.364636 & $4,419.60$ \\
\hline & & Table 1 & & & \\
\hline & & & &
\end{tabular}

Table -1

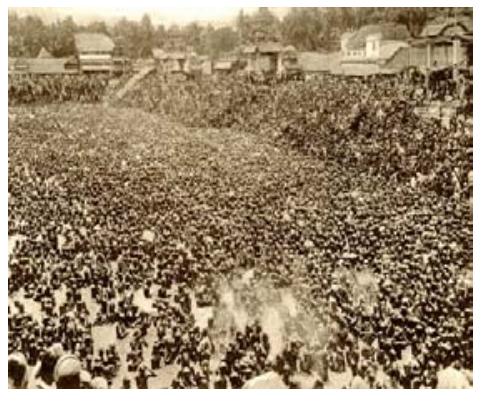

The image shows the people taking a hold dip in Mahamagam Tank in the year 1900

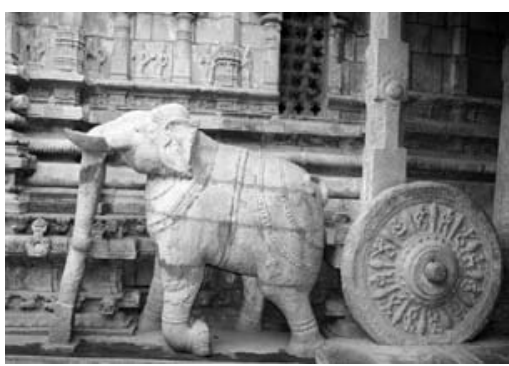

The image shows the intricate detail of Nageswara Temple

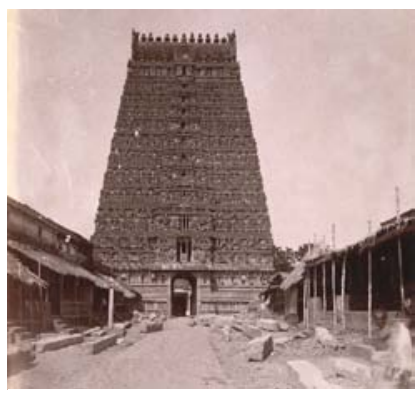

The image shows the front Gopuram of Sarangapani Temple in the year 1892

(Images downloaded from http://www.justknow.in/Kumbakonam/Gallery-List/ct-1/City-OLD-Photos)

\section{CONCLUSION}

Kumbakonam is one of the hydro centric towns with lot of heritage characters in tangible and intangible aspects. Collecting and recording the characters of the temple town will help for the sustainability of the town. As GIS is the one which works with cartographic points, it is a suitable tool to work with the macro level planning and the issues can be solved in grounded way. The maps show a various heritage potential of the town and proper design strategy could be carried out to preserve the same.

\section{REFERENCES}

[1] Geographical information systems database of cultural heritage resources of Osogbo and their tourism potential, African Journal of Hospitality, Tourism and Leisure Vol. 3 (2) - (2014).

[2] Dr. Balu A, Senthilkumar A , A perspective on pilgrimage tourism in Thanjavur district, International Journal of Applied Research 2016; 2(4): 116-120

[3] Dr Kuldeep Pareta , Remote sensing and Gis based site suitability analysis for tourism development , International Journal of Advanced Research in Engineering and Applied Sciences. Vol. 2 | No. 5 | May 2013

[4] Walter Jamieson, Cultural Heritage Tourism Planning and Development: Defining the Field and It’s Challenges, APT Bulletin 29, No. 3/4 (1998): 65.

[5] GIS Applications for an Effective Heritage Tourism Management in Romania, International Journal of Economic Practices and Theories, Vol. 5, No. 2, 2015. 
[6] Mohamed R. Bualhamam, The study of urban growth impact in tourism area using remote sensing and GIS technique for north part of the UAE , Journal of Geography and Regional Planning Vol. 2(6), pp. 166-175, June, 2009.

[7] P. Carl, Kumbakonam Art Architecture and Urbanism, Space: Ritual and Meaning in a Sacred - Royal City of South India, Cambridge University, U.K. 1998.

[8] Hariharan.S (2012) Planning for pedestrian infrastructure in a heritage town- Kumbakonam (Unpublished Master Thesis) School of Architecture and Planning , Anna University, Chennai.

[9] Nimisha Drolia (2012) Temple town of Kumbakonam, IIT Bombay Unpublished manuscript. 